\title{
MONITORIA SOROLÓGICA DA MICOPLASMOSE EM PLANTÉIS DE AVES REPRODUTORAS NO BRASIL ATRAVÉS DO TESTE DE SOROAGLUTINAÇÃO RÁPIDA
}

\author{
A.L.S.P. Cardoso, E.N.C. Tessari, A.G.M. de Castro, A.M.I. Kanashiro, G.F.Z. Stoppa
}

${ }^{1}$ Instituto Biológico, Centro Avançado de Pesquisa Tecnológica do Agronegócio Avícola, Rua Bezerra Paes, 2278, CEP 13690-000, Descalvado, SP, Brasil. E-mail: alspcardoso@terra.com.br

\section{RESUMO}

O estudo foi conduzido com o objetivo de avaliar sorologicamente 952 lotes de galinhas reprodutoras com idade entre 6 e 65 semanas, de diversas regiões do País durante os anos de 2003 e 2004. Foram analisadas 139.096 e 121.818 amostras de soro através da prova de soroaglutinação rápida para Mycoplasma gallisepticum e Mycoplasma synoviae, respectivamente. Os soros foram inativados a $56^{\circ} \mathrm{C}$, por 30 min e processados à prova de soroaglutinação rápida com antígenos comerciais. Adicionou-se partes iguais de antígeno e soro, homogenizando a mistura e após $2 \mathrm{~min}$ verificou-se a presença ou não de grumos, indicando a formação de reação antígeno-anticorpo. Inicialmente utilizou-se soro bruto, e posteriormente soro diluído na proporção de 1:10 em salina $0,85 \%$ de NaCl. Das amostras analisadas, 1,58\% (1920) apresentaram resultado positivo na diluição 1:10 ao antígeno testado de MS e negativas ao antígeno testado de M. gallisepticum. Considerandose esses resultados pode-se suspeitar da presença de $M$. synoviae nesses plantéis, indicando que a prova de soroaglutinação rápida pode ser utilizada preliminarmente como monitoria, facilitando a conduta laboratorial a ser seguida, direcionando outros testes sorológicos e ações de isolamento e a identificação dos agentes com maior precisão.

PALAVRAS-CHAVE: Biossegurança, Mycoplasma gallisepticum,Mycoplasma synoviae, soroaglutinação.

\section{ABSTRACT}

SEROLOGIC MONITORING OF MYCOPLASMOSIS IN BREEDER CHICKENS IN BRAZIL BY RAPID SERUM AGGLUTINATION TEST. This study was conducted to evaluate the serological responses of 952 flocks of breeder chickens with ages between 6 and 65 weeks, from several areas of the country during the years of 2003 and 2004. A total of 139,096 and 121,818 serum samples were analyzed by rapid serum agglutination test for Mycoplasma gallisepticum and Mycoplasma synoviae, respectively. The sera were inactivated at $56^{\circ} \mathrm{C}$, for $30 \mathrm{~min}$ and processed by the rapid serum agglutination test with commercial antigens. Similar parts of antigen and serum were added, the solution was mixed and after $2 \mathrm{~min}$ the presence or not of clots was verified, indicating the antigenantibody formation. Initially crude serum was used, and later serum diluted in the proportion of $1: 10$ in saline $0.85 \%$ of $\mathrm{NaCl}$. Of the analyzed samples, $1.58 \%$ (1920) resulted positive for the tested antigen in the dilution 1:10 of M. synoviae and negative for $M$. gallisepticum. Considering these results, the presence of MS in these flocks can be suspected, indicating that rapid serum agglutination test can be used as a control, to facilitate the laboratorial procedures followed, leading to other serological tests and isolation actions and the identification of agents with greater precision.

KEY WORDS: Biosecurity, Mycoplasma gallisepticum, Mycoplasma synoviae, serum agglutination.

\section{INTRODUÇÃO}

A micoplasmose aviária é considerada um dos principais problemas da avicultura mundial. OMycoplasma gallisepticum (MG) é o agente etiológico da doença respiratória crônica das galinhas e da sinusite infecciosa dos perus (Yoder, 1991; NAscimento, 2000).

Os micoplasmas têm causado preocupação na avicultura industrial desde sua descoberta. O MG e Mycoplasma synoviae (MS) causam doenças crônicas endêmicas e são transmitidos verticalmente através de ovos contaminados. Uma vez introduzido na granja, um micoplasma patogênico é de difícil eliminação, requerendo na maioria das vezes a despopulação do ambiente para o sucesso da erradicação do agente (LAURIMAR, 2005).

A infecção por MS pode ser caracterizada por doença inaparente do trato respiratório superior, podendo evoluir para aerossaculite (KLEVEN, 1991; NASCIMENTO, 2001), sendo responsável por grandes 
perdas econômicas na avicultura, atribuídas à redução na eficiência alimentar, às altas taxas de mortalidade, aos gastos com medicamento è condenação de carcaça (EWING,1998; NAscimento, 2001).

O impacto causado pelos micoplasmas não está somente na redução de produtividade. A situação é agravada pela estrutura piramidal praticada na avicultura, na qual os problemas que afetam plantéis básicos multiplicadores potencializam-se nos próximos níveis da produção quando transmitidos verticalmente. O ideal é criar aves livres de ambos, MG e MS. Isso é logrado com a obtenção de aves oriundas de plantéis livres destes organismos para se evitar a transmissão vertical, as quais são então criadas em granjas com boa biosseguridade para evitar então a infecção por via horizontal (LAURIMAR, 2005).

No Brasil, a vigilância oficial para MG e MS é exercida pelo Ministério da Agricultura, Pecuária e Abastecimento (MAPA) através do Plano Nacional de Sanidade Avícola (PNSA), que conceitua os diferentes estabelecimentos da produção avícola, bem como determina ações a serem seguidas para certificação dos lotes, incluindo as exigências de biosseguridade e os testes laboratoriais a serem procedidos. Para um bom diagnóstico deve-se considerar o histórico da granja juntamente com exames sorológicos. Metodologias baseadas em testes sorológicos foram estabelecidas para atender a vigilância necessária à garantia de se certificar a negatividade dos lotes. A soroaglutinação rápida (SAR) é o teste de triagem mais realizado como procedimento sorológico inicial para aferir plantéis de aves livres de micoplasmoses. Se o soro apresentar reação à diluição igual ou superior a 1:10, o resultado é considerado positivo, e são confirmados utilizandoseotesteELISA ou teste deinibição da hemaglutinação (HI), além de técnicas de biologia molecular. A certificação é conferida pelo MAPA para lotes com resultados negativos em 100 amostras de soros testadas em SAR às 12 semanas de vida, 150 amostras testadas quando oloteatingir $5 \%$ de produção de ovos econsecutivamentea cada três meses, sempreefetuados em laboratório credenciado pelo MAPA (BRASIL, 1994; BRASIL, 1999).

A SAR é uma prova simples para monitorar o estado de saúde de plantéis avícolas, dotada de grande sensibilidade para a detecção dos anticorpos, porém, requer de especificidade quanto à identificação do agente. Assim, deve-se usar provas mais específicas para suporte de um diagnóstico mais preciso (MENDONÇa et al., 1998; RosAles, 1999). A SAR detecta principalmente anticorpos do tipo IgM, que aparecem 3-5 dias após o início da infecção e que persistem por 70 a 80 dias (NASCIMENTO, 2000).

Pela literatura e através do Serviço de Vigilância Epidemiológica, desconhece-se a real prevalência de MS em nosso país. Nas décadas de 60 e 70 no Estado de Minas Gerais, estudos delineados para se conhecer a situação das aves contaminadas com MG, encontrou-se prevalências destemicroorganismo em $25,7 \%$ dos lotes avaliados através de isolamento e 32,8\%-33,4\% através de testes sorológicos (RESENDE et al., 1968; Reiset al., 1973). Entretanto, as informações dos profissionais envolvidos na avicultura apontam para uma prevalência aproximada de $100 \%$ nos plantéis avícolas brasileiros (NASCIMENTO, 2001).

O objetivo deste estudo foi monitorar lotes de reprodutoras para micoplasmoses através de SAR, mostrando a importância do procedimento sorológico como teste de triagem para MG e MS, para a identificação de plantéis avícolas positivos e para orientar na seleção de medidas de profilaxia.

\section{MATERIAL E MÉTODOS}

No ano de 2003 e 2004, foram analisadas 139.096 e 121.818 amostras de soros através da prova deSAR para MG e MS, respectivamente. Estes soros foram provenientes de 952 lotes de galinhas reprodutoras de criatórios com idade entre 6 e 65 semanas, de diversas regiões do Brasil. As amostras foram analisadas através do teste sorológico de soroaglutinação rápida em placa (SAR), utilizando antígeno comercial Intervet para MG e MS, considerando-se data de fabricação e data do produto. Os soros foram centrifugados, inativados $5^{\circ} \mathrm{C}$, por $30 \mathrm{~min}$ e submetidos a reações aglutinantes com antígeno para os agentes mencionados. $\mathrm{O}$ teste consiste em adicionar partes iguais de antígeno e soro, homogenizando a mistura e após 2 min verificou-se a presença ou não de grumos, indicando a formação da reação de antígenoanticorpo. Primeiramente, empregou-se a prova de SAR utilizando soro bruto. Os soros que apresentaram positividade frente aos antígenos testados, foram diluídos na proporção 1:10 em salina 0,85\% de $\mathrm{NaCl}$. A prova foi realizada em placa de vidro padrão, onde reagiram $25 \mathrm{~mL}$ de antígeno $+25 \mathrm{~mL}$ de soro, por um período de dois minutos. Para fins de classificação inequívoca dos soros das aves pela prova de SAR, foram considerados positivos, segundo BRASIL (1994), para MGeMS, aqueles que apresentaram aglutinação na diluição 1:10 na SAR.

\section{RESULTADOS E DISCUSSÃO}

Das 139.096 amostras de soros testadas frente ao antígeno de MS, observou-se que 1,58\% (1.920/ 139.096) reagiram positivamente na diluição 1:10, totalizando 23 lotes positivos. 
Quando avaliamos os resultados dos 952 lotes de galinhas frente ao antígeno de MG, observamos que estes apresentaram-se negativos na SAR diluída 1:10 frente ao antígeno testado de MG, corroborando com os resultados de Orsi et al. (2004).

Em nossos estudos, o ano de 2003 apresentou menor percentual de lotes positivos para MS (1,48\%), quando foi coletado o maior número de amostras (81.558). No ano de 2004, coletou-se menor número de amostras (40.260) com maior percentual de amostras positivas para MS $(1,77 \%)$.

MENDONÇA et al. (2003) observaram um grau significativo para a presença de MG e MS em um plantel de galinhas poedeiras. $\mathrm{O} M G$ mostrou-se muito prevalente $(41,65 \%)$ em relação ao MS $(11,10 \%)$ considerando as diluições iguais ou superiores a 1:10 na SAR.

Entre dezembro de 1997 e maio de 2003, Orsi et al. (2004) observaram que ocorreu maior percentual de positividadenaSAR para MS no ano de1997, o que pode indicar um controle mais eficiente nos últimos anos. Dentre as 4212 amostras de soro testadas para a pesquisa de anticorpos anti-MS, 213 (5,1\%) mostraram-se positivas na diluição 1:10.

No ano de 2002, CARDoso et al. (2003) observaram positividade na SAR para MS de 19,54\% em galinhas reprodutoras de empresas oriundas do Estado de São Paulo.

A infecção por MS em granja de reprodutoras é altamente relevante tendo em vista a capacidade de transmissão vertical do agente (Orsi et al., 2004).

Os resultados de MendOnçA et al. (2004) de soros de matrizes pesadas submetidos à SAR revelaram percentagem de positividade para MG de20\% naSAR diluída 1:10.

Os levantamentos sorológicos têm sido empregados para amparar programas de controle de micoplasmoses (SATO, 1996).

Conforme Buchala(2003), omonitoramentoperiódico assegura a manutenção da condição das granjas livres da infecção, evitando a transmissão para a progênie.

\section{CONCLUSÃO}

O emprego da sorologia na prática deve ser um instrumento constante na rotina dos laboratórios de patologia aviária. A prova de SAR inicialmente empregada para evidenciação de MG e MS deve ser usada como procedimento sorológico para aferir plantéis livres de micoplasmas nas criações de frangos de corte, galinhas e outras aves reprodutoras.

Embora a prova de SAR tenha demonstrado negatividade para MG nesses plantéis de reprodução, nãoé possível afirmar que os lotes testados estejam livres do agente.

Em relação ao MS, os resultados obtidos alertam para a presença do agente nos lotes de aves reprodutoras, ainda que em baixas percentagens. Assim, faz-se necessário usar provas sorológicas mais específicas e o isolamento do agente para sua caracterização.

\section{REFERÊNCIAS}

BRASIL. Ministério da Agricultura, Secretaria de Defesa Agropecuária, Departamento de Defesa Animal. Normas técnicas para o controle e a certificação de núcleos ou estabelecimento avícola livres de micoplasmoses aviárias. Diário Oficial da União,n.24, Seção I, Brasília, 1 de julho de 1999.

Brasil. Programa Nacional de Sanidade Avícola. Atos legais. Portaria Ministerial 193. Diário Oficial da República Federativa do Brasil, Poder Executivo, Brasília, DF, 19 de setembro de 1994.

Buchala, F.G. Levantamento sorológico de Salmonella e Mycoplasma em aves domésticas de criatórios de explorações não tecnificadas "fundo de quintal" no Estado de São Paulo. 2003. 67f. Dissertação (Mestrado) - UniversidadeEstadual Paulista, Faculdade de Ciências Agrárias e Veterinárias, Jaboticabal, 2003.

CardosoA.L.S.P.;T ESSARI E.N.C.;CASTRO A.G.M.; Kanashiro A.M.I.; Zanatta G.F. Prova de soroaglutinação rápida em galinhas reprodutoras como monitoria sorológica de micoplasmoses. Arquivos do Instituto Biológico, São Paulo, v.70, 2003. Suplemento 3. Trabalho apresentado na REUNIÃO ANUAL DOINSTITUTO BIOLÓGICO, 16., 2005, São Paulo. Resumos . Disponível em: <http:www.biologico.sp.gov.br/ arquivos/v70_suplemento23/raib.pdf.> Acesso em: 16 nov. 2005.

Ewing, M.L.; CoOKSON, K.C.; Phillips, R.A.; Turner, K.R.; Kleven, S.H. Experimental infection and transmissibility of Mycoplasmasynoviae with delayed serologic response in chickens. Avian Diseases, v.42, n.2, p.230-238, 1998.

Kleven, S.H.; Rowland, G.N.; Olson, N.O. Mycoplasma synoviae infection. In: CALNEK, B.W.; BARNES, H.J.; BeARd, C.W.; Reid, W.M.; Yoder Junior, H.W. (Eds.). Diseases of poultry. 9.ed. Ames: IowaState University Press, 1991. p.223-231.

LAURIMAR, F. Vacinas evacinações para micoplasmas. In: Ave Expo Américas 2005; FORUMINTERNACIONAL DE AVICULTURA, 1., 2005, Foz do Iguaçu, PR. Anais. Foz do Iguaçu: 2005. p.32-34.

Mendonça, G.A.; Nascimento, E.R.; Lignon, G.B.; Pólo, P.A. O emprego das provas de SAR e HI como rotina laboratorial para evidenciação de Mycoplasma gallisepticum (MG). Revista Brasileira de Ciência Avícola, p.177, 2004. Suplemento 6. Trabalho apresentado na CONFERENCIAAPINCODECIÊNCIASE TECNOLOGIA AVÍCOLAS, 2004, Campinas. Resumos.

Mendonça, G.A.; Nascimento, E.R.; Nascimento, M.G.F., LignON, G.B., BONACORSI, R.A. Resposta sorológica de galinhas poedeiras comerciais vacinadas com MG-F. Brasileira de Ciência Avícola, p.63, 1998. Suplemento. Trabalho apresentado na CONFERÊNCIA 
APINCODECIÊNCIASETECNOLOGIAAVÍCOLAS, 1998, Campinas. Resumos.

Mendonça, G.A.; Pólo, P.A.; Nascimento, E.R.; Lignon, G.B. A prova deSAR em galinhas poedeiras infectadas por micoplasmoses e salmoneloses. Revista Brasileira de Ciência Avícola, p.116, 2003. Suplemento 5. Trabalho apresentado na CONFERÊNCIA APINCODE CIÊNCIAS E TECNOLOGIA AVÍCOLAS, 2003, Campinas. Resumos.

Nascimento, E.R. Micoplasmoses. In: Berchieri Júnior, A. \& MACARI, M. (Eds.).Doenças dasaves. Campinas:FACTA, 2000. p.217-224.

Nascimento, E.R. Mycoplasma Synoviae em avicultura - implicações econômicas: conviver ou erradicar? In: CONFERÊNCIA APINCO DE CIÊNCIAS E TECNOLOGIA AVÍCOLAS, 2001, Campinas, SP.Anais . Campinas: 2001. v.1, p.31-44.

Orsi, M.A.; Rbeiro, S.A.; Ferrati, A.R.; Mendonça, A.O.; Silva, E.V. Estudo soroepidemiológico da micoplasmose em plantéis de aves reprodutoras no Brasil. Revista Brasileira de Ciência Avícola, p.176, 2004. Suplemento 6. Trabalho apresentado na CONFERÊNCIA APINCO DE CIÊNCIAS E TECNOLOGIA AVÍCOLAS, 2004, Campinas. Resumos.
Reis, R.; Resende, M.; Ornellas-Santos, P.P.; Yamamoto, R.; OliveIra, R.L. Micoplasmoses animais. I. Freqüência de M. meleagridis e M. gallisepticumem perus em Minas Gerais. Arquivos da Escola de Veterinária, v.24, p.197199, 1973.

Resende, M.; Reis, R.; Gettelfinger, J.P. Micoplasma de origem aviária. I. Isolamento e agrupamento sorológico. Arquivos da Escola de Veterinária, v.20, p.175-185, 1968.

RosALES, A.G. Monitoria sorológica em aves. In: CONFERÊNCIA APINCO DE CIÊNCIAS E TECNOLOGIA AVÍCOLAS, 1., 1999, Campinas, SP.Anais.Campinas, 1999. v.1, p.46-52.

SAto, S. Avian mycoplasmosis in Asia.Revue Scientifique et Technique Office International des Epizooties, v.15, n.4, p.1555-1567, 1996.

Yoder Junior, H.W. Mycoplasma gallisepticum infection. In: CalneK, B.W.; Barnes, H.J.; Beard, C.W.; Reid, W.M.; Yoder Junior, H.W. (Eds.). Diseases of poultry. 9.ed. Ames: Iowa State University Press, 1991. p.198-212.

Recebido em 8/12/05

Aceito em 10/2/06 